\title{
Childhood Thyroid Gland Carcinoma
}

National Cancer Institute

\section{Source}

National Cancer Institute. Childhood Thyroid Gland Carcinoma. NCI Thesaurus. Code C118827.

A rare carcinoma of the thyroid gland that occurs during childhood. 